\title{
Identification of two plant viruses using partial purification and mass spectrometry
}

\author{
Paul L. Guy ${ }^{1} \cdot$ Richard Easingwood $^{2}$ - Diana L. Carne ${ }^{3} \cdot$ Torsten Kleffmann $^{3}$
}

Received: 1 September 2014 / Accepted: 18 March 2015 /Published online: 27 March 2015

(C) Australasian Plant Pathology Society Inc. 2015

\begin{abstract}
Serological and PCR techniques failed to detect Tomato spotted wilt virus (TSWV) infecting stunted tomato plants exhibiting leaf curling, purpling and crumpling. In contrast, Mass Spectrometry rapidly identified peptides generated from a $\sim 28 \mathrm{kD}$ protein cut from PAGE gels as TSWV N-protein within 5 days. The results indicate that the incidence of TSWV may be underestimated in the field. Cocksfoot mild mosaic virus (CMMV) was identified infecting Bromus diandrus using serological techniques. Peptides from a $\sim 25 \mathrm{kD}$ protein failed to identify with any protein on GenBank until a CMMV sequence was published. The use of Mass Spectrometry as an adjunct for virus detection and identification is briefly discussed.
\end{abstract}

Keywords Virus identification · Mass spectrometry · Cocksfoot mild mosaic virus · Tomato spotted $\cdot$ Wilt virus

Paul L. Guy

paul.guy@otago.ac.nz

1 Botany Department, University of Otago, Box 56, Dunedin 9054, New Zealand

2 Otago Centre for Electron Microscopy, University of Otago, Dunedin, New Zealand

3 Centre for Protein Research, Biochemistry Department, University of Otago, Dunedin, New Zealand
Virus detection and identification have evolved steadily over the last 100 years. Early techniques, including mechanical and insect transmission tests, do not rely on prior knowledge of the virus concerned (Kado and Agrawal 1972; Wilson 2014). Electron microscopy does not rely on prior knowledge of the virus and generally provides information on the size, shape and some surface features of virus particles (Hull 2002; Wilson 2014). In contrast serology and PCR based techniques rely on prior knowledge of which viruses are likely to be present in a sample and may require many rounds of diagnosis before a successful identification (Cooper et al. 2003; Zheng et al. 2011). More recently Next Generation Sequencing has revolutionised the identification of viruses and other organisms (Wilson 2014). Another technique which does not rely on prior knowledge is Mass Spectrometry (MS). Increasing numbers of viruses have been identified and interactions with host proteomes have been characterised (Zheng et al. 2011). MS has been used to study a few plant viruses (Cooper et al. 2003; Seifers et al. 2005; Luo et al. 2010) but this technique is under-utilised (Blouin et al. 2010). In this paper we examine the utility of using MS to identify two plant viruses.

Tomato plants (cv Sub Arctic Plenty) showing leaf curling, crumpling, purpling and stunting (but not yellowing) and a wild grass (Bromus diandrus) showing mosaic symptoms were collected from a farm at Waitati, East Otago NZ. The lack of virus particles in leaf dip preparations suggested that a low titre virus was present in the tomato samples. The presence of isometric particles without distinct subunit structure suggested the presence of a bromo-, sobemo- or tombus-virus in the grass samples.

Tomato samples were tested for 15 viruses (Table 1) by ELISA, using kits (Agdia, Adgen, Loewe) in accordance with 
Table 1 Tomato sample ELISA

\begin{tabular}{|c|c|c|c|}
\hline Antisera & $\begin{array}{l}\text { Source } \\
\text { (Catalog } \\
\text { no.) }\end{array}$ & $\begin{array}{l}\text { Viruses detected } \\
\text { according to the } \\
\text { manufacturer }\end{array}$ & $\begin{array}{l}\text { Results: all } \\
\text { negative for } \\
\text { the tomato } \\
\text { sample }\end{array}$ \\
\hline Alfalfa mosaic virus & $\begin{array}{l}\text { Agdia } \\
\text { (SRA } \\
87601 \text { ) }\end{array}$ & AMV & \\
\hline $\begin{array}{l}\text { Arabis mosaic } \\
\text { virus }\end{array}$ & $\begin{array}{l}\text { Agdia } \\
\text { (SRA } \\
23201 \text { ) }\end{array}$ & ArMV & \\
\hline Begomoviruses & $\begin{array}{l}\text { Adgen } \\
\text { (1073) }\end{array}$ & $\begin{array}{l}\text { Tomato and } \\
\text { others }\end{array}$ & \\
\hline $\begin{array}{l}\text { Cucumber } \\
\text { mosaic virus }\end{array}$ & $\begin{array}{l}\text { Agdia } \\
\text { (SRA } \\
44501)\end{array}$ & CMV & \\
\hline Potyviruses & $\begin{array}{l}\text { Agdia } \\
\text { (SRA } \\
27200)\end{array}$ & many & \\
\hline $\begin{array}{l}\text { Strawberry latent } \\
\text { ringspot virus }\end{array}$ & $\begin{array}{l}\text { Agdia } \\
\text { (SRA } \\
14000)\end{array}$ & SLRV & \\
\hline $\begin{array}{l}\text { Tobacco } \\
\text { ringspot virus }\end{array}$ & $\begin{array}{l}\text { Agdia } \\
\quad \text { (SRA } \\
64000)\end{array}$ & TRSV & \\
\hline $\begin{array}{l}\text { Tomato bushy } \\
\text { stunt virus }\end{array}$ & $\begin{array}{l}\text { Agdia } \\
\quad \text { (SRA } \\
454000)\end{array}$ & TBSV & \\
\hline $\begin{array}{l}\text { Tomato } \\
\text { ringspot virus }\end{array}$ & $\begin{array}{l}\text { Agdia } \\
\text { (SRA } \\
22000)\end{array}$ & ToRSV & \\
\hline \multicolumn{4}{|l|}{ Tospoviruses } \\
\hline $\begin{array}{l}\text { Tomato spotted wilt } \\
\text { \&Impatiens } \\
\text { necrotic spot } \\
\text { viruses }\end{array}$ & $\begin{array}{l}\text { Agdia } \\
\text { (SRA } \\
\text { 30400) }\end{array}$ & TSWV \& INSV & \\
\hline $\begin{array}{l}\text { Tospo Broad } \\
\text { Range }\end{array}$ & $\begin{array}{l}\text { Loewe } \\
\qquad(07507)\end{array}$ & $\begin{array}{l}\text { TSWV, TCSV, } \\
\text { GRSV, INSV }\end{array}$ & \\
\hline $\begin{array}{l}\text { Iris yellow } \\
\text { spot virus }\end{array}$ & $\begin{array}{l}\text { Loewe } \\
\qquad(07508)\end{array}$ & IYSV & \\
\hline
\end{tabular}

the manufacturers' instructions. The tomato samples tested negative for all these viruses. Two isolates of Tomato spotted wilt virus (TSWV) from dahlia were used as positive controls. The Alfonso (Dahlia cultivar) isolate caused chlorotic ringspot and oakleaf patterns in infected leaves. The Pam Howden (Dahlia cultivar) isolate caused a diffuse chlorotic mottle. Both dahlia isolates tested positive in TSWV ELISA tests.

The brome grass samples were tested for 8 viruses by ELISA and 20 viruses using Ouchterlony double diffusion tests done in sodium acetate $(50 \mathrm{mM}$ sodium acetate, $0.15 \mathrm{M}$ sodium chloride, $0.2 \%$ sodium azide, $0.75 \%$ agarose;
pH6) gels using antisera diluted $1 / 10$ to viruses known to infect the Poaceae and to a selection of sobemoviruses (Table 2). The grass samples tested positive for Cocksfoot mild mosaic virus (CMMV), CMMV-Phleum mottle and Panicum mosaic virus (PMV).

RNA was purified from tomato and dahlia leaf tissue. Samples (ca. 3-20 mg) of leaves were homogenized with $200 \mu \mathrm{l}$ STE buffer $(0.1 \mathrm{M} \mathrm{NaCl}, 10 \mathrm{mM}$ Tris, $\mathrm{pH} 8.0,1 \mathrm{mM}$ ETDA, pH 8.0) with $500 \mu$ of Trizol (Sigma) in a Beadbeater ${ }^{\mathrm{TM}}$. After $5 \mathrm{~min}$ incubation at room temperature, $100 \mu \mathrm{L}$ of chloroform was added to the homogenates and, after vigorous shaking, the homogenates were centrifuged at $14,000 \mathrm{~g}$ for $10 \mathrm{~min}$. A half volume (ca. $250 \mu \mathrm{L}$ ) of isopropanol was added to the aqueous phase to precipitate RNA from the supernatant. Samples were incubated at room temperature for $10 \mathrm{~min}$. After centrifuging at $14,000 \mathrm{~g}$ for $8 \mathrm{~min}$ the supernatants were discarded and the pellets were washed twice in $75 \%$ ethanol. Air dried pellets were resuspended in DEPC-treated water. Each sample was processed separately; sterilized barrier pipette tips, freshly autoclaved solutions and DEPC treated water (negative controls) were used for each procedure. Total RNA (1-5uL) was used to produce cDNA and amplified via PCR using the Superscript III One-Step RT-PCR System (Invitrogen) $\left(50^{\circ} \mathrm{C}\right.$ for $30 \mathrm{~min}$, $94{ }^{\circ} \mathrm{C}$ for 2 min then 35 cycles: $94{ }^{\circ} \mathrm{C} 30 \mathrm{~s}, 54^{\circ} \mathrm{C} 35 \mathrm{~s}, 72^{\circ} \mathrm{C}$ $1 \mathrm{~min} ; 72^{\circ} \mathrm{C} 2 \mathrm{~min}$ ). A two-step RT-PCR was also used. Reverse transcription was done using AMV and RNAsin (Promega) and reverse primer (Table 3) for $55 \mathrm{~min}$ in a thermal cycler at $42{ }^{\circ} \mathrm{C}$. Following the RT reaction PCR was done using Platinum Taq $\left(94{ }^{\circ} \mathrm{C}\right.$ for 1 min then 30 cycles: $94{ }^{\circ} \mathrm{C}$ $1 \mathrm{~min}, 55^{\circ} \mathrm{C} 1 \mathrm{~min}, 72^{\circ} \mathrm{C} 1 \mathrm{~min} ; 72^{\circ} \mathrm{C} 10 \mathrm{~min}$ ). The PCR was then repeated using the same cDNA and primers (Table 3 ) at a lower annealing temperature $\left(94^{\circ} \mathrm{C}\right.$ for 5 min then 35 cycles: $94{ }^{\circ} \mathrm{C} 30 \mathrm{~s}, 48^{\circ} \mathrm{C} 40 \mathrm{~s}, 72{ }^{\circ} \mathrm{C} 40 \mathrm{~s} ; 72{ }^{\circ} \mathrm{C} 5 \mathrm{~min}$ ). Freeze-dried tomato leaf material was also sent to Agdia Inc USA for RTPCR analyses.

None of the tomato samples tested positive for any of the viruses in house or at the Agdia testing service. The dahlia isolates were used as positive controls in house and an unspecified isolate was used as a positive control at the Agdia testing service.

Leaf material ground in liquid nitrogen was combined with $0.1 \mathrm{M}$ potassium phosphate containing $1 \% 2$ mercaptoethanol and $0.75 \%$ sodium sulfite $(w / v)$ (tomato) or $0.5 \mathrm{M}$ acetate buffer (Brome grass) and emulsified with $1 / 10$ volume of chloroform. The aqueous phase was made to $0.2 \mathrm{M}$ sodium chloride and polyethylene glycol 6000 was added $(6 \% w / v)$. The precipitate was collected by low speed 
Table 2 Brome grass serology

\begin{tabular}{|c|c|c|c|}
\hline Antisera & Source (Catalog no.) & Viruses detected $^{\mathrm{a}}$ & Result $^{\mathrm{b}}$ \\
\hline Agropyron mosaic virus & R. Plumb, UK & AgMV & \\
\hline Brome mosaic virus & Agdia (SRA 29300) & BMV & \\
\hline BMV-Julius & R. Sward, Australia & BMV & \\
\hline BMV-Rhdolf & R. Sward, Australia & BMV & \\
\hline Brome streak mosaic virus & Loewe $((07123)$ & BStMV & \\
\hline Cocksfoot streak virus & L Torrance, Scotland & CSV & \\
\hline Cocksfoot mild mosaic virus & W. Huth, Germany & CMMV & ++ \\
\hline CMMV-Phleum mottle & W. Huth, Germany & CMMV & ++ \\
\hline Cocksfoot mottle virus & W. Huth, Germany & CoMV & \\
\hline Foxtail mosaic virus & B. Falk, USA & FMV & \\
\hline Ginger chlorotic fleck virus & J. Thomas, Australia & GCFV & \\
\hline Lucerne transient streak virus & R. Forster, NZ & LTSV, CoMV & \\
\hline Maize chlorotic mottle virus & B. Falk, USA & MCMV & \\
\hline Maize stripe virus & Agdia (SRA 17300) & $\mathrm{MSpV}$ & \\
\hline Maize white line virus & B. Falk, USA & MWLV & \\
\hline Panicum mosaic virus & B. Falk, USA & PMV, CMMV & + \\
\hline Potyviruses & Agdia (SRA 27200) & many & \\
\hline Rice yellow mottle virus & American Type Culture Collection (ATTC 516) & RYMV & \\
\hline Rice necrosis mosaic virus & R. Plumb, UK & RNMV & \\
\hline Ryegrass mosaic virus & D. Webster, NZ & RGMV & \\
\hline Solanum nodiflorum mottle virus & R. Greber, Australia & SNMV & \\
\hline Soilborne wheat mosaic virus & Agdia (SRA 42001) & SBWMV & \\
\hline Southern bean mosaic virus & American Type Culture Collection (ATTC 298, 300) & SBMV & \\
\hline Sugarcane bacciliform virus & Agdia (SRA 72200) & SCBV & \\
\hline Subclover mottle virus & R. Jones, Australia & SCMV & \\
\hline Velvet tobacco mottle virus & J. Randles, Australia & VTMoV & \\
\hline Wheat dwarf virus & Loewe (07082) & WDV & \\
\hline Wheat streak mosaic virus & Agdia (SRA 47001) & WSMV & \\
\hline
\end{tabular}

${ }^{\mathrm{a}}$ according to the source, ${ }^{\mathrm{b}}$ blank cells represent no reaction to brome grass extracts: ++ distinct precipitin line in double diffusion tests, + less distinct line in double diffusion tests

centrifugation $(5,000 \mathrm{~g})$ after stirring for $3 \mathrm{~h}$ at $4{ }^{\circ} \mathrm{C}$. Pellets were resuspended in buffer and after low speed centrifugation $(5,000 \mathrm{~g})$ were re-pelleted in a Sorvall Ultracentrifuge (100,
$000 \mathrm{~g}$ ) for $2 \mathrm{~h}$. The final high speed pellets (and other fractions) were resuspended in distilled water and Laemli loading buffer and analysed using BioRad minigel polyacrylamide gel
Table 3 Primers used for tomato sample RT-PCR

\begin{tabular}{llll}
\hline Target virus & Primers (Reverse primer) & Expected size & Reference \\
\hline Tomato spotted wilt virus & $\begin{array}{l}\text { TCTGGTAGCATTCAACTTCAA } \\
\text { (GTTTCACTGTAATGTTCCATAG) }\end{array}$ & $628 \mathrm{bp}$ & Roberts et al. 2000 \\
& $\begin{array}{l}\text { TGTAITGITCCATIGCA } \\
\text { (AGAGCAATIGTGTCA) }\end{array}$ & Mumford et al. 1996 \\
& $\begin{array}{l}\text { GTGTCATACTTCTTTGGGTC } \\
\text { (GGGAGAGCAATYGWGKYR) }\end{array}$ & $709 \mathrm{bp}$ & Kuwabara et al. 2010 \\
\hline
\end{tabular}




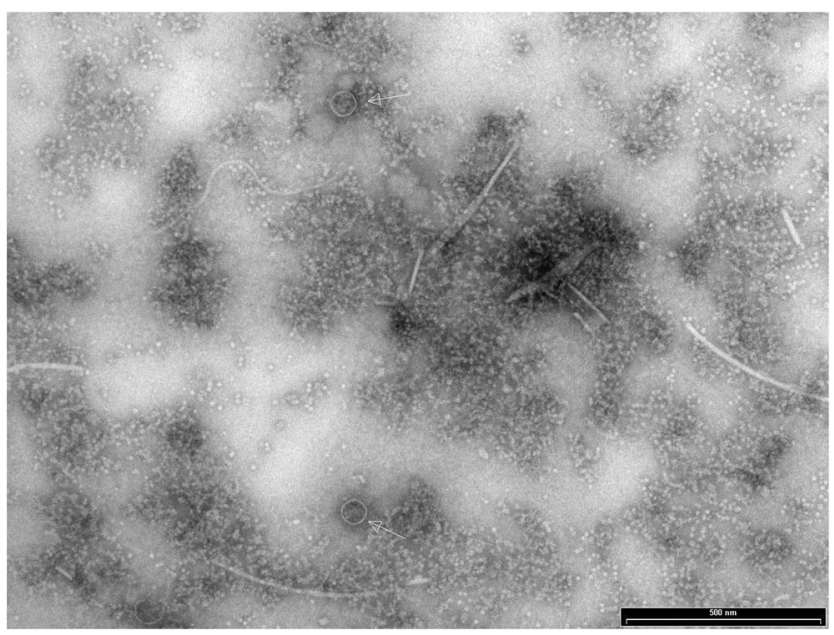

Fig. 1 TEM image of purified tomato extract: arrows indicate Tomato spotted wilt virus particles

electrophoresis (PAGE) on 10-20\% polyacrylamide gradient gels. Bands were cut from Coomassie R250 stained/destained gels for analysis by mass spectrometry (MS) at the University of Otago, Centre for Protein Research.

A prominent $\sim 28 \mathrm{kD}$ band (tomato) and a $\sim 25 \mathrm{kD}$ band (brome grass: only band on gel) were cut from gels for analysis by mass spectrometry (MS). Samples of high speed pellets resuspended in distilled water were mixed with phosphotungstate and examined in a Philips transmission electron microscope. The tomato samples contained damaged membrane

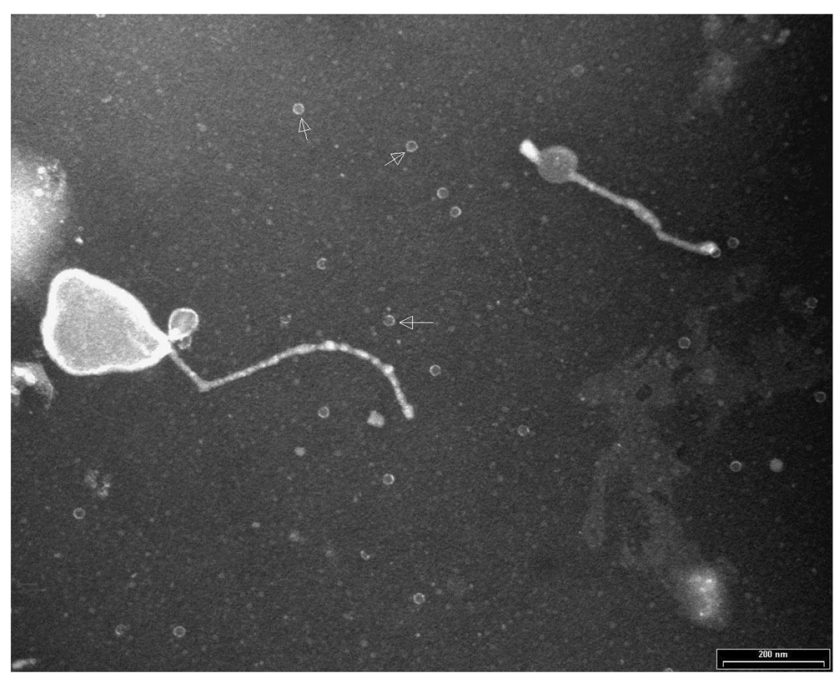

Fig. 2 TEM image of purified brome grass extract: arrows indicate Cocksfoot mild mosaic virus particles bound particles $\sim 75 \mathrm{~nm}$ in diameter associated with nucleoprotein resembling tospovirus particle preparations (Fig. 1) and the grass samples contained numerous $\sim 30 \mathrm{~nm}$ particles (Fig. 2) mentioned above.

The proteins of interest were digested in-gel using protease (Table 4) and the resulting peptides were subjected to MALDI tandem Time-of-Flight (TOF/TOF) MS. Fragment ion spectra were searched against the NCBI nr database using the Mascot search engine (www.matrixscience.com). For the grass sample, which was not identified by Mascot, a de novo sequencing mass spectrometry approach (Chen et al. 2004) was applied. Following tandem mass spectrometry peptide ions were fragmented sequentially using laser desorption and each individual amino acid was identified by its mass to charge ratio. These data were interpreted manually and assembled into peptide sequences (Table 4). The assembled peptides were searched against the NCBI database.

Partial purification followed by PAGE and MS rapidly identified a $\sim 28 \mathrm{kD}$ band as the $\mathrm{Mr}=28.8 \mathrm{kD} \mathrm{N}$-protein of TSWV. The nine identified peptides (Table 1) covered $48 \%$ of the N-protein target sequence. Many contaminating peptides from photosynthetic proteins, mostly Rubisco, were also identified (data not shown). The successful detection and identification of TSWV and other tospoviruses is often time consuming and involves multiple techniques (Mumford et al. 1996; Dietzgen et al. 2005). This current study shows that MS is a useful tool for detecting and identifying TSWV.

Initial MS data on a $\sim 25 \mathrm{kD}$ band from the grass sample PAGE produced no matches with the NCBI nr databases and sequence tags derived from de novo sequencing. Following the publication of the CMMV sequence (Ziegler et al. 2009) the $\sim 25 \mathrm{kD}$ band was identified as the $26.5 \mathrm{kD}$ coat protein of CMMV. The five identified peptides (Table 1) covered $20 \%$ of the target sequence. Seven of the 56 amino acids in the 5 peptides were mismatched with the target sequence indicating variation between the Scottish and NZ isolates of CMMV.

Considerable time and effort is required to identify plant viruses using serological and PCR techniques (Wilson 2014). Each candidate virus has to be tested individually by buying in antibodies and primers and ordering more antibodies and primers when other possible diagnoses become apparent. Extensive testing of the tomato samples failed to detect TSWV. It is uncertain which of the TSWV structural proteins react with the antibodies in the Agdia and Loewe kits. The RT-PCRs were designed to amplify segments on the N-protein gene but the in-house assays and the Agdia testing service failed to detect the 
Table 4 Summary of peptide sequences detected by mass spectrometry

\begin{tabular}{|c|c|c|c|c|}
\hline Virus targeted & Digest & Peptides identified & $\begin{array}{l}\text { Published seq. } \\
\text { length }\end{array}$ & Coverage \\
\hline $\begin{array}{l}\text { TSWV } \\
\text { gi } 535099 \\
\text { (and } 17 \text { other TSWV } \\
\text { N-protein sequences) }\end{array}$ & Trypsin & $\begin{array}{l}\text { ESIVALLTQGK } \\
\text { DLEFEEDQNLVAFNFK } \\
\text { TFCLENLDQIKK } \\
\text { MSVISCLTFLK } \\
\text { IGATDMTFR } \\
\text { LVEETGNSENLNTIK } \\
\text { IASHPLIQAY GLPLDDAK } \\
\text { AFEMNEDQVKK } \\
\text { GSIAMEHYSETLNKFYEMFGVK }\end{array}$ & 258 & $48 \%$ \\
\hline $\begin{array}{l}\text { CMMV } \\
\text { NC } 011108\end{array}$ & $\begin{array}{l}\text { Papain+Trypsin } \\
\text { Trypsin }\end{array}$ & $\begin{array}{l}\text { RPLAYgQaVGP } \\
\text { TQPEIILR } \\
\text { LHSQHeWR } \\
\text { VVLKFFPNYR } \\
\text { LEDLMDtSsLTfSPYEkHT }\end{array}$ & 245 & $\begin{array}{l}20 \% \\
\text { (lower case letter codes } \\
\text { were mismatches with } \\
\text { the published amino } \\
\text { acid sequence) }\end{array}$ \\
\hline
\end{tabular}

tomato isolate of TSWV but succeeded in detecting two Dahlia isolates in-house and an unknown isolate at Agdia Inc. PCR assays vary in their robustness (Wilson 2014) and unexpected sequence variation is a major limitation for PCR based techniques (Zheng et al. 2011). For example, Osman et al. (2007) found using multiple isolates of six Grapevine leafroll associated viruses that individual primer pairs detected $54-89 \%$ of their collected isolates. Osman et al. (2007) used nine pairs of primers in their RT-PCR study. The relatively simple partial purification, PAGE electrophoresis followed by MS identified TSWV within 5 days. A similar effort was mounted to test the grass samples serologically. CMMV was more readily purified than TSWV however, initially, the identified peptides did not match any sequence on GenBank. After the publication of a CMMV sequence, the peptides were identified as part of the CMMV coat protein. The speed and utility of using MS to identify plant viruses is limited by the number of virus species' sequences lodged with databases. As modern shotgun sequencing techniques become more accessable and cheaper these databases become more comprehensive and MS will become an increasingly useful adjunct in virus identification. Mass Spectrometry analysis has the advantage that it analyses proteins, rather than nucleic acids, and therefore does not rely on the analysis of both DNA and RNA to be complete.

The tomato plants did not display the bronzing pattern on leaves typically associated with TSWV infection. Chamberlain (1954) noted that occasionally TSWV infected tomatoes show the symptoms outlined for the Waitati samples. The fact that the tomato isolate remained undetected by
ELISA and RT-PCR indicates that the incidence of this virus may be under estimated in the field.

Acknowledgments Thanks to the University of Otago and the Brenda Shore Trust for financial support and to an anonymous referee for constructive criticism.

Compliance with ethical standards The authors have no conflict of interest to declare.

\section{References}

Blouin AG, Greenwood DR, Chavan RR, Pearson MN, Clover GRG, MacDiarmid RM, Cohen D (2010) A generic method to identify plant viruses by high-resolution tandem mass spectrometry of their coat proteins. J Virol Methods 163:49-56

Chamberlain EE (1954) Plant virus diseases in New Zealand. NZ DSIR Bull 108:88

Chen P, Nie S, Mi W, Wang XC, Liang SP (2004) De novo sequencing of tryptic peptides sulfonated by 4-sulfophenyl isothiocyanate for unambiguous protein identification using post-source decay matrixassisted laser desorption/ionization mass spectrometry. Rapid Commun Mass Spectrom 18:191-198

Cooper B, Eckert D, Andon NL, Yates JR, Haynes PA (2003) Investigative proteomics: identification of an unknown plant virus from infected plants using mass spectrometry. J Am Soc Mass Spectrom 14:736-741

Dietzgen RG, Twin J, Talty J, Selladurai S, Carroll ML, Coutts BA, Berryman DI, Jones RAC (2005) Genetic variability of tomato spotted wilt virus in Australia and validation of real time RT-PCR for its detection in single and bulked leaf samples. Ann Appl Biol 146: $517-530$

Hull R (2002) Matthews' plant virology, 4th edn. Academic, London, $1001 \mathrm{pp}$ 
Kado CI, Agrawal HO (1972) Principles and techniques in plant virology. Van Nostrand Reinhold, New York, 688 pp

Kuwabara K, Yokoi N, Ohki T, Tsuda S (2010) Improved multiplex reverse transcription-polymerase chain reaction to detect and identify five tospovirus species simultaneously. J Gen Plant Pathol 76: 273-277

Luo H, Wylie SJ, Jones MGK (2010) Identification of plant viruses using one-dimensional gel electrophoresis and peptide mass fingerprints. $\mathrm{J}$ Virol Methods 165:297-301

Mumford RA, Barker I, Wood KR (1996) An improved method for the detection of Tospoviruses using the polymerase chain reaction. $\mathrm{J}$ Virol Methods 57:109-115

Osman F, Leutenegger C, Golino D, Rowhani A (2007) Real-time RTPCR assays for the detection of Grapevine leafroll associated viruses 1-5 and 9. J Virol Methods 141:22-29
Roberts CA, Dietzgen RG, Heelan LA, Maclean DJ (2000) Real-time RTPCR fluorescent detection of tomato spotted wilt virus. J Virol Methods 88:1-8

Seifers DL, Harvey TL, Martin TJ, Haber S, She YM, Ens W, Standing KG, Salomon R, Gera A (2005) Association of a virus with wheat displaying yellow head disease symptoms in the great plains. Plant Dis 89:888-895. doi:10.1094/PD-89-0888

Wilson CR (2014) Diagnosis and detection methods. Applied Plant Virology. CABI International, Wallingford UK pp 103-128. ISBN 9781845939915

Zheng J, Sugrue RJ, Tang K (2011) Mass spectrometry based proteomic studies on viruses and hosts- a review. Anal Chim Acta 702:149 159

Ziegler A, Cowan G, Torrance L (2009) Comparative sequence analysis and serological and infectivity studies indicate that cocksfoot mild mosaic virus is a member of the genus Panicovirus. Arch Virol 154: $1545-1549$ 